\title{
Pharmacy Technician Job Satisfaction with Communication and Relationships Factors in Saudi Arabia
}

\begin{abstract}
Yousef Ahmed Alomi* iD, The Former General Manager of General Administration of Pharmaceutical Care, Former Head, National Clinical Pharmacy and Pharmacy Practice, Former Head, Pharmacy R\&D Administration, Ministry of Health, Riyadh, SAUDI ARABIA.
\end{abstract}

Faiz A. Bahadig Rph, Informatics Pharmacist, Pharmaceutical Care Department, King Abdul-Aziz Medical, City-WR-Jeddah, Ministry of National Guard, SAUDI ARABIA.

Reem Saad Alsubaie, Pharmacy Services, Prince Sultan Military Medical City, Riyadh, SAUDI ARABIA.

Bayan Ibrahim Alghuraybi, Pharmacy Services, Prince Sultan Military Medical City, Riyadh, SAUDI ARABIA.

Budoor Emad Aloumi, Pharmacist, Pharmaceutical Care Services, Ministry of National Guard - Health Affairs. KAMC Central Region, SAUDI ARABIA.

\section{Correspondence:}

Yousef Ahmed Alomi, (Bsc. Pharm, MSc. Clin Pharm, BCPS, BCNSP, DiBA, CDE) The Former General Manager of General Administration of Pharmaceutical Care, Former Head, National Clinical Pharmacy and Pharmacy Practice, Former Head, Pharmacy R\&D Administration, Ministry of Health, Riyadh, SAUDI ARABIA.

Phone no: +966 504417712

E-mail:yalomi@gmail.com

Received: 14-03-2019;

Accepted: 16-05-2019

Copyright: ๑ the author(s),publisher and licensee Pharmacology, Toxicology and Biomedical Reports. This is an open-access article distributed under the terms of the Creative Commons Attribution NonCommercial License, which permits unrestricted non-commercial use, distribution, and reproduction in any medium, provided the original work is properly cited.

This is an open access article distributed under the terms of the Creative Commons Attribution-NonCommercial-ShareAlike 4.0 License

Access this article online

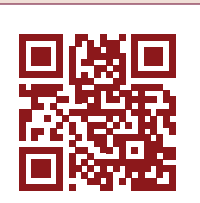

www.ptbreports.org

DOI:

10.5530/PTB.2019.5.26

\begin{abstract}
Purpose: To explore the Pharmacy technician job satisfaction with Communication and relationships factors in Saudi Arabia. Methods: It is a 4-months cross-section survey of the stress factors impacting pharmacy technician job satisfaction in Saudi Arabia. The study consisted of 35 questions divided into two-part demographic information and the second part consisted of three parts. Part one was about stress-related factors of pharmacy job. Part two included the questions about pharmacy services units of pharmacy job. Part three questions about communication and relationships factors of pharmacy technician job. In addition, overall job satisfaction. The questionnaire made as an electronic format and it was analyzed through survey monkey system about part three communication and relationships factors of pharmacy technician job. Results: The total responders were 96. The gender distribution 83 $(86.46 \%)$ was male and $13(13.54 \%)$ was female. The majority of them $86(89.58 \%)$ were in age group (20-39) years. The average satisfaction score of pharmacy supervisors' factors was (3.175), pharmacy technician interaction with other healthcare providers' factors was (3.38). While the customer interaction was (3.45) the pharmacy technician relationship with coworkers was (3.85). Most of the pharmacy technician found the challenges at their job were $(79.2 \%)$. Some responders wished to change their pharmacy career $(60 \%)$ previously while $(78 \%)$ liked to stay in the pharmacy field. The overall job satisfaction scores were (3.62). Conclusion: Most of the pharmacy technicians were not satisfied with their job because the supervisor was not supportive and as they faced challenges in their work. Management tool to all pharmacy staff including the supervisors and pharmacy technician in the culture work is highly recommended at healthcare institutions in the Kingdom of Saudi Arabia.

Key words: Pharmacy technician, Job satisfaction, Communication, Relationships, factors, Saudi Arabia.
\end{abstract}

\section{INTRODUCTION}

The pharmacy technicians had a functional role in providing pharmaceutical care to the patients. The American Society of Health-System Pharmacist standardized the role of pharmacy technicians. The pharmacy technicians assess the pharmacist in his or her patient care and provide pharmaceutical care. That is including preparation of medications, repacking of drugs, filling the medications, monitoring of inventory control, pharmacy automation. ${ }^{1-3}$ Besides, the pharmacy technicians can help the clinical pharmacy services through documentation of clinical activities, explore the laboratory test and receiving drug information inquiries. ${ }^{3-5}$ All previous duties contribute the job satisfaction in the work to accomplish the goals. ${ }^{6}$ The job satisfaction needs several aspects of measurement, including communication elements, stress job avoidance, pharmacy work. The pharmacy technicians full-fill the communications requirement of healthcare providers. They need skills to communicate with pharmacy supervisors and staff, physician, nurses and all allied health care professionals. Several overseas studies have been published in the field of pharmacy technician's job satisfaction..$^{7-10}$ However, based on the best knowledge of the authors, there are seldom investigations done in the Kingdom of Saudi Arabia or Gulf and Middle East countries about Pharmacy technician's job satisfaction. The aim of the study to explore the communication aspect of pharmacy technician's job satisfaction in Saudi Arabia.

\section{METHODS}

It is a 4-months cross-section survey of the stress factors impact of pharmacy technician job satisfaction in Saudi Arabia. The study consisted of 35 questions divided into two-part demographic information and the second part consisted of three parts. Part one was about stress-related factors of pharmacy job. It included pharmacy management policies, pharmacy stress factors, pharmacy personnel time, salary and benefits, pharmacy motivation factors. Part two included the questions about pharmacy services units of pharmacy job. It included pharmacy management structure, dispensing and patient education, clinical pharmacy services, pharmacy technology, pharmacy store and overall job satisfaction. Part three questions about communication and relationship factors of pharmacy technician job. It included pharmacy supervisors, relationship with coworkers and pharmacist interaction with other healthcare providers, customer interaction and overall job satisfaction. The 5-point Likert response scale system closed and ended questions were used. Several factors involved in the analysis of pharmacy technician's job satisfaction (gender, age, social status, experiences current position, salary). The questionnaire was made as an electronic format and it analyzed through survey monkey system about part three communication and re- 
lationship factors of pharmacy technician job.

\section{RESULTS}

The total responders were 96 . Of those $96(100 \%)$ was Saudi and $0(0$ $\%)$ was non-Saudi. The gender distribution $83(86.46 \%)$ was male and $13(13.54 \%)$ was female. The majority of them 86 (89.58 \%) were in age group (20-39 years). Most of the pharmacy technicians were married $67(74.44 \%)$ while 23 (25.56\%) were singles (Table 1$)$. In an age (30-39 years) more male gender than age (20-30 years) with significant differences $(p<0.05)$. While in age $(20$-30 years $)$ more female gender than the male with significant differences $(p<0.05)$. In an age $(30-39$ years) more marriage than single status (20-30 years) with significant differences $(p<0.05)$. While in age $(20-30$ years $)$ more single than marriage status with significant differences $(p<0.05)$.

Most of the pharmacy technicians worked at outpatient pharmacy 50 (59.52\%) compared to inpatient pharmacy 24 (28.57\%). In all age categories, there are no significant differences between all categories at current pharmacy works $(p>0.5)$. The most responders spent less than three were $28(29.17 \%)$ three years, followed by six to ten years $26(27.08 \%)$ and three to five years $24(25.00 \%)$ and working in the current position. In an age (30-39) more total years of experience ( $p>6$ years) in the current position than age (20-30 years) with significant differences $(p<0.05)$. While in age (20-30 years) more total years of experience ( $<3$ years) than age (30-39 years) with significant differences $(p<0.05)$.

While more of responders receive 7,000-9,000 SR monthly salary 45 (47.87\%) and 10,000-12,000 SR monthly salary 32 (34.04\%) (Table 2). In an age (30-39 years) more salary (10,000 and above SR) than age (20-30 years) with significant differences $(p<0.05)$. While in age $(20-30$ years $)$

Table 1: Demographic social information.

\begin{tabular}{|c|c|c|}
\hline Nationality & Response Count & Response Percent \\
\hline Saudi & 95 & $100.00 \%$ \\
\hline Non-Saudi & 0 & $0.00 \%$ \\
\hline Answered question & 95 & \\
\hline Skipped question & 1 & \\
\hline Gender & Response Count & Response Percent \\
\hline Male & 83 & $86.46 \%$ \\
\hline Female & 13 & $13.54 \%$ \\
\hline Answered question & 96 & \\
\hline Skipped question & 0 & \\
\hline Age & Response Count & Response Percent \\
\hline$<19$ & 0 & $0.00 \%$ \\
\hline 20-29 & 36 & $37.50 \%$ \\
\hline $30-39$ & 50 & $52.08 \%$ \\
\hline $40-49$ & 10 & $10.42 \%$ \\
\hline 50-59 & 0 & $0.00 \%$ \\
\hline$>60$ & 0 & $0.00 \%$ \\
\hline Answered question & 96 & \\
\hline Skipped question & 0 & \\
\hline Marital status & Response Count & Response Percent \\
\hline Single & 23 & $25.56 \%$ \\
\hline Married & 67 & $74.44 \%$ \\
\hline Other (please specify) & 0 & $0.00 \%$ \\
\hline Answered question & 90 & \\
\hline Skipped question & 6 & \\
\hline
\end{tabular}

more salary (7,000-9,000 SR) than age (30-39 years) with significant differences $(p<0.05)$. In salary income $(10,000-12,000$ SR) more marriage than salary income (7,000-9,000 SR) with significant differences $(p<0.05)$. While in the salary income $(7,000-9,000 \mathrm{SR})$ more singular than salary income (10,000-12,000 SR) with significant differences $(p<0.05)$. In salary income $(10,000-12,000 \mathrm{SR})$ more working at the primary care center and continue to stay in the Pharmacy field than salary income $(7,000-9,000 \mathrm{SR})$ with significant differences $(p<0.05)$.

Most of the responders worked at Ministry of health 48 (50\%) followed by $\mathrm{MOH}$ government Hospital $24(25.00 \%)$ and private Hospital 16 $(16.67 \%)$. In an age (30-39 years) more working at $\mathrm{MOH}$ than $\mathrm{MOH}$ hospitals $(20-30$ years) with significant differences $(p<0.05)$. While in age (20-30 years) more $\mathrm{MOH}$ hospitals than $\mathrm{MOH}$ with significant differences $(p<0.05)$.

The responders worked at ( $<50$ beds) hospitals $14(20.00 \%)$ followed by (100-199 beds) 13 (18.57\%) and (200-299 beds) hospitals 11 (15.71\%) and the most hospitals accredited by Saudi Commission for Health Specialties 44 (57.14\%) followed by Saudi Central Board for Accreditation of Healthcare Institutions (CBAHI) 24 (31.17\%) and Joint commission of

Table 2: Demographic responder qualifications information.

\begin{tabular}{|c|c|c|}
\hline The practice area & $\begin{array}{l}\text { Response } \\
\text { Count }\end{array}$ & $\begin{array}{c}\text { Response } \\
\text { Percent }\end{array}$ \\
\hline Inpatient Pharmacy & 24 & $28.57 \%$ \\
\hline Outpatient Pharmacy & 50 & $59.52 \%$ \\
\hline Narcotics & 1 & $1.19 \%$ \\
\hline Extemporaneous Preparation & 1 & $1.19 \%$ \\
\hline Inventory Control & 0 & $0.00 \%$ \\
\hline Emergency pharmacy & 4 & $4.76 \%$ \\
\hline Drug Information & 0 & $0.00 \%$ \\
\hline All (All previous sections) & 2 & $2.38 \%$ \\
\hline PCC pharmacy & 2 & $2.38 \%$ \\
\hline Pharmacy licensees & 1 & $1.19 \%$ \\
\hline Answered question & 84 & \\
\hline Skipped question & 12 & \\
\hline $\begin{array}{l}\text { Total years you worked in current } \\
\text { position }\end{array}$ & $\begin{array}{l}\text { Response } \\
\text { Count }\end{array}$ & $\begin{array}{c}\text { Response } \\
\text { Percent }\end{array}$ \\
\hline$<3$ & 28 & $29.17 \%$ \\
\hline 3-5 & 24 & $25.00 \%$ \\
\hline 6-10 & 26 & $27.08 \%$ \\
\hline $11-15$ & 6 & $6.25 \%$ \\
\hline$>15$ & 12 & $12.50 \%$ \\
\hline Answered question & 96 & \\
\hline Skipped question & 0 & \\
\hline Monthly income & $\begin{array}{l}\text { Response } \\
\text { Count }\end{array}$ & $\begin{array}{c}\text { Response } \\
\text { Percent }\end{array}$ \\
\hline$<6.000$ & 2 & $2.13 \%$ \\
\hline $7.000-9.000$ & 45 & $47.87 \%$ \\
\hline $10.000-12.000$ & 32 & $34.04 \%$ \\
\hline $14,000-16,000$ & 9 & $9.57 \%$ \\
\hline $18,000-20,000$ & 5 & $5.32 \%$ \\
\hline$>25.000$ & 1 & $1.06 \%$ \\
\hline Answered question & 94 & \\
\hline Skipped question & 2 & \\
\hline
\end{tabular}


Table 3: Demographic hospital information.

\begin{tabular}{|c|c|c|}
\hline Sector of work & Response Count & $\begin{array}{l}\text { Response } \\
\text { Percent }\end{array}$ \\
\hline Ministry of Health & 48 & $50.00 \%$ \\
\hline $\begin{array}{l}\text { General Medical Directorate in } \\
\text { Region }\end{array}$ & 2 & $2.08 \%$ \\
\hline MOH government Hospital & 24 & $25.00 \%$ \\
\hline Non- MOH government Hospital & 5 & $5.21 \%$ \\
\hline MOH-Primary Care Center & 1 & $1.04 \%$ \\
\hline Private Hospital & 16 & $16.67 \%$ \\
\hline Community pharmacy & 0 & $0.00 \%$ \\
\hline Other (please specify) & 0 & $0.00 \%$ \\
\hline Answered question & 96 & \\
\hline Skipped question & 0 & \\
\hline Number of beds at your hospital & Response Count & $\begin{array}{c}\text { Response } \\
\text { Percent }\end{array}$ \\
\hline$<50$ & 14 & $20.00 \%$ \\
\hline $50-99$ & 6 & $8.57 \%$ \\
\hline 100-199 & 13 & $18.57 \%$ \\
\hline $200-299$ & 11 & $15.71 \%$ \\
\hline 300-399 & 9 & $12.86 \%$ \\
\hline $400-499$ & 5 & $7.14 \%$ \\
\hline 500-599 & 4 & $5.71 \%$ \\
\hline$=$ or $>600$ & 2 & $2.86 \%$ \\
\hline Medical City & 6 & $8.57 \%$ \\
\hline Answered question & 70 & \\
\hline Skipped question & 26 & \\
\hline The hospital accreditation & Response Count & $\begin{array}{l}\text { Response } \\
\text { Percent }\end{array}$ \\
\hline CIBAHI & 24 & $31.17 \%$ \\
\hline Joint Commotion USA & 9 & $11.69 \%$ \\
\hline Canada & 0 & $0.00 \%$ \\
\hline $\begin{array}{l}\text { Saudi commission of health } \\
\text { accreditation }\end{array}$ & 44 & $57.14 \%$ \\
\hline Answered question & 77 & \\
\hline Skipped question & 19 & \\
\hline
\end{tabular}

hospital accreditations USA 9 (11.69\%) (Table 3). In all age categories, there are no significant differences between all categories at hospital bed capacity $(p>0.5)$.

The average satisfaction score of pharmacy supervisors' factors was (3.175), in an age (20-30 years) more disagree of the supervisors had their job functions than age (30-39 years) with significant differences $(p<0.05)$. Pharmacy technician interaction with other healthcare providers' factors was (3.38) (Table 4 and 5). While the customer interaction was (3.45) the pharmacy technician relationship with coworkers was (3.85). In all age categories, there are no significant differences between all categories with the communication of healthcare professionals, customers, coworkers and patient's education satisfaction elements $(p>0.5)$. Most of the pharmacy technician who found challenges at their job
Table 4: Pharmacy technician satisfaction on supervisor's relationship.

\begin{tabular}{|c|c|c|c|c|c|c|c|c|}
\hline & Supervisors & 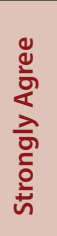 & ఫัँ & 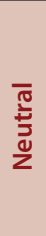 & 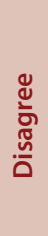 & 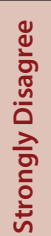 & 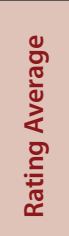 & 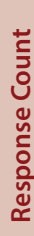 \\
\hline 1 & $\begin{array}{l}\text { My supervisors } \\
\text { provide competent and } \\
\text { consistent supervision. }\end{array}$ & 20 & 25 & 26 & 19 & 6 & 3.35 & 96 \\
\hline 2 & $\begin{array}{l}\text { My supervisors give me } \\
\text { a sufficient amount of } \\
\text { information (feedback) } \\
\text { about how well I am } \\
\text { doing my job. }\end{array}$ & 19 & 28 & 27 & 13 & 9 & 3.36 & 96 \\
\hline 3 & $\begin{array}{l}\text { My supervisors have an } \\
\text { adequate knowledge of } \\
\text { their jobs. }\end{array}$ & 15 & 21 & 35 & 18 & 7 & 3.20 & 96 \\
\hline 4 & $\begin{array}{l}\text { My supervisors give } \\
\text { ample consideration to } \\
\text { employee complaints } \\
\text { and pharmacy issues and } \\
\text { respond to them in a } \\
\text { timely manner. }\end{array}$ & 11 & 29 & 18 & 23 & 15 & 2.98 & 96 \\
\hline 5 & $\begin{array}{l}\text { My supervisors teach } \\
\text { pharmacist the proper } \\
\text { dealing with various } \\
\text { types of patients. }\end{array}$ & 13 & 26 & 25 & 21 & 11 & 3.09 & 96 \\
\hline 6 & $\begin{array}{l}\text { My supervisors teach the } \\
\text { pharmacist professional } \\
\text { pharmaceutical / } \\
\text { management related } \\
\text { skills. }\end{array}$ & 8 & 27 & 19 & 29 & 12 & 2.89 & 95 \\
\hline 7 & $\begin{array}{l}\text { My supervisors help } \\
\text { the pharmacist in } \\
\text { identifying potential } \\
\text { unavailable products in } \\
\text { pharmacy but available } \\
\text { in warehouse or other } \\
\text { pharmacies. }\end{array}$ & 16 & 28 & 27 & 16 & 8 & 3.29 & 95 \\
\hline 8 & $\begin{array}{l}\text { My supervisor provides } \\
\text { constructive criticism to } \\
\text { employees. }\end{array}$ & 11 & 32 & 26 & 16 & 8 & 3.24 & 93 \\
\hline & Average & & & & & & 3.175 & \\
\hline
\end{tabular}

were (79.2\%). Some responders wished to change their pharmacy career (60\%) previously while (78\%) liked to stay in the pharmacy field. The overall job satisfaction scores were (3.62) (Table 6). The finding showed for gender factor there are no significant differences between male or female and social status (married or single), experiences of current position and most of salary income factors for all communication parameters $(p>0.5)$. In all age categories, there are no significant differences between all categories at overall job satisfaction elements $(p>0.5)$.

\section{DISCUSSION}

This study was conducted to assess the status of job satisfaction among pharmacy technician's in the country of Saudi Arabia. The current study is the first done in Saudi Arabia about communication factors of Phar- 
Table 5: The Pharmacy technician interaction with other healthcare providers' factors.

\begin{tabular}{|c|c|c|c|c|c|c|c|c|}
\hline & $\begin{array}{l}\text { Negative / Positive } \\
\text { interactions with health } \\
\text { care providers }\end{array}$ & 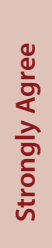 & 㐫 & 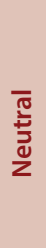 & 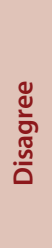 & 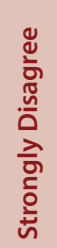 & 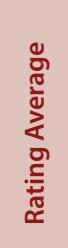 & 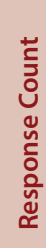 \\
\hline 1 & $\begin{array}{l}\text { Physicians are } \\
\text { uncooperative when I } \\
\text { must communicate with } \\
\text { them about "job-related" } \\
\text { matters. }\end{array}$ & 17 & 27 & 30 & 21 & 1 & 3.40 & 96 \\
\hline 2 & $\begin{array}{l}\text { Physicians consult with } \\
\text { me often on professional } \\
\text { matters. }\end{array}$ & 5 & 41 & 29 & 16 & 3 & 3.31 & 94 \\
\hline 3 & $\begin{array}{l}\text { Nurses are uncooperative } \\
\text { when I initiate } \\
\text { communication with } \\
\text { them about "job-related" } \\
\text { matters. }\end{array}$ & 6 & 29 & 24 & 29 & 6 & 3.00 & 94 \\
\hline 4 & $\begin{array}{l}\text { Nurses often initiate } \\
\text { consultation with me on } \\
\text { professional matters. }\end{array}$ & 12 & 42 & 27 & 12 & 2 & 3.53 & 95 \\
\hline 5 & $\begin{array}{l}\text { Non- pharmacists often } \\
\text { perform functions that } \\
\text { should only be performed } \\
\text { by a pharmacist. }\end{array}$ & 11 & 22 & 24 & 27 & 10 & 2.97 & 94 \\
\hline 6 & $\begin{array}{l}\text { Technicians are respected } \\
\text { by other health care } \\
\text { providers. }\end{array}$ & 16 & 35 & 19 & 12 & 14 & 3.28 & 96 \\
\hline 7 & $\begin{array}{l}\text { Technicians are } \\
\text { cooperative at the } \\
\text { pharmacy. }\end{array}$ & 39 & 42 & 9 & 4 & 2 & 4.17 & 96 \\
\hline & Average & & & & & & 3.38 & \\
\hline
\end{tabular}

macy technician's job satisfaction. The majority of responders were Saudi that has expected because there is no academic institution graduate nonSaudi pharmacy technicians. Besides, most of the responders were male because in the last years opened the female branch of pharmacy technicians. Most of the responders were higher age and were married while younger old pharmacy technicians were single. That is expected in social life in Gulf counties. Most of the pharmacy technicians worked at an outpatient pharmacy and one-third of them worked at inpatient services. That is expected because of most of the pharmacy technicians trained at outpatient services. Also, the inpatient services were not ideal system with Intravenous admixture services. As a result, the majority of works were at outpatient siting and needed more pharmacy staff. The majority of responders were higher age old with more 6-10 years' experience with range 10,000-12,000 young age with few years of experience and 7,0009,000 range salary. That is excepted and normal situation of a pharmacy technician's career leader salary and employment in Saudi Arabia.

The findings of the study showed that is pharmacy technicians not fully satisfied with their supervisor's related factors with similar of previous study. ${ }^{7}$ That is related to the main reasons were the supervisors did not teach the pharmacy technicians the management skills or job how to deal with patients and the supervisors not responded promptly if there are any problems occurred. The pharmacy technician's communication not reached the optimal level with other healthcare providers. That is related to some functions done by non-pharmacy technicians and the nurses uncooperative with pharmacy technicians. The pharmacy technician's communication with customers was accepted with similar of previous study. ${ }^{7}$ That is related to the patient to follow the instructions of pharmacy technicians and comply with them. Pharmacy technician's communication with a coworker was accepted because most of the staff are deal friendly and received recognition from them. The majority of pharmacy technicians had challenges in their make then not satisfied with the job. Maybe lead to more than half of responders wished to change their pharmacy field previously. However, with getting old two third of responders liked to continue in the pharmacy career. The overall pharmacy technician's job satisfaction was acceptable. Several aspects reduce pharmacy satisfaction related to the supervisor. ${ }^{7}$

Table 6: The Pharmacy technician relationship with Customers and coworkers.

\begin{tabular}{|c|c|c|c|c|c|c|c|c|}
\hline & Customer interactions & $\begin{array}{l}\text { Strongly } \\
\text { Agree }\end{array}$ & Agree & Neutral & Disagree & $\begin{array}{l}\text { Strongly } \\
\text { Disagree }\end{array}$ & $\begin{array}{c}\text { Rating } \\
\text { Average }\end{array}$ & $\begin{array}{c}\text { Response } \\
\text { Count }\end{array}$ \\
\hline 1 & $\begin{array}{l}\text { Patients show appreciation for the services } \\
\text { I provide for them. }\end{array}$ & 16 & 28 & 32 & 14 & 5 & 3.38 & 95 \\
\hline 2 & $\begin{array}{l}\text { In general, I find that patients (customers) } \\
\text { attempt to comply with the directions and } \\
\text { advice I give them. }\end{array}$ & 9 & 45 & 30 & 8 & 3 & 3.52 & 95 \\
\hline & Average & & & & & & 3.45 & \\
\hline \multicolumn{9}{|c|}{ Answered question 95, Skipped question 1} \\
\hline & Relationships with coworkers & $\begin{array}{l}\text { Strongly } \\
\text { Agree }\end{array}$ & Agree & Neutral & Disagree & $\begin{array}{l}\text { Strongly } \\
\text { Disagree }\end{array}$ & $\begin{array}{c}\text { Rating } \\
\text { Average }\end{array}$ & $\begin{array}{c}\text { Response } \\
\text { Count }\end{array}$ \\
\hline 1 & The people with whom I work are friendly. & 26 & 47 & 20 & 2 & 1 & 3.99 & 96 \\
\hline 2 & $\begin{array}{l}\text { I receive recognition and a sense of } \\
\text { personal worth from my colleagues. }\end{array}$ & 32 & 43 & 15 & 4 & 0 & 4.1 & 94 \\
\hline 3 & $\begin{array}{l}\text { All of my coworkers in the pharmacy are } \\
\text { highly competent. }\end{array}$ & 15 & 32 & 30 & 17 & 1 & 3.45 & 95 \\
\hline & Average & & & & & & 3.85 & \\
\hline
\end{tabular}




\begin{tabular}{|c|c|c|c|c|c|c|c|c|}
\hline \multirow{2}{*}{\multicolumn{9}{|c|}{$\begin{array}{l}\text { Table 6: Con' } \\
\text { Answered question 96, Skipped question } 0\end{array}$}} \\
\hline & & & & & & & & \\
\hline \multirow[b]{2}{*}{1} & Overall job satisfaction & $\begin{array}{l}\text { Strongly } \\
\text { Agree }\end{array}$ & Agree & Neutral & Disagree & $\begin{array}{l}\text { Strongly } \\
\text { Disagree }\end{array}$ & $\begin{array}{l}\text { Rating } \\
\text { Average }\end{array}$ & $\begin{array}{l}\text { Response } \\
\text { Count }\end{array}$ \\
\hline & I find challenge in my work. & 33 & 37 & 15 & 11 & 0 & 3.96 & 96 \\
\hline 2 & $\begin{array}{l}\text { Knowing what I know now, if I had to } \\
\text { decide all over again whether to go into } \\
\text { pharmacy, I would choose another field. }\end{array}$ & 25 & 14 & 12 & 26 & 19 & 3.0 & 96 \\
\hline \multirow[t]{2}{*}{3} & $\begin{array}{l}\text { If I were free to pursue any type of career I } \\
\text { wanted, I would stay in pharmacy. }\end{array}$ & 32 & 35 & 20 & 5 & 4 & 3.9 & 96 \\
\hline & Average & & & & & & 3.62 & \\
\hline
\end{tabular}

\section{CONCLUSION}

Our results suggest that policies governing the pharmacy technician profession need to be talked with more apprehension as the level of job satisfaction, is relatively low-slung and may generate monetary and work force problems in Saudi Arabia. Pharmacy technician's job satisfaction has not reached to the optimal level. The pharmacy technicians had communication challenges with supervisor and healthcare professionals. More than half wished to change the Pharmacy field. Targeting of an annual survey of pharmacy technician's job satisfaction related to communication factors is required in Saudi Arabia.

\section{ACKNOWLEDGEMENT}

None.

\section{CONFLICT OF INTEREST}

The authors declare that there are no conflicts of interest.

\section{ABBREVIATIONS}

KSA: Kingdom of Saudi Arabia; MOH: Ministry of Health; B.Sc. Pharm: Bachelor in pharmacy; Pharm D: Doctor of Pharmacy; CBAHI: Saudi Central Board for Accreditation of Healthcare Institutions.

\section{ORCID ID}

Yousef Ahmed Alomi (iD https://orcid.org/0000-0003-1381-628X

\section{REFERENCES}

1. American Society of Health-System Pharmacists. ASHP statement on the roles of pharmacy technicians. Am J Heal Pharm. 2016;73(5):329-32.

2. American Society of Health-System Pharmacists. ASHP statement on the pharmacy technician's role in pharmacy informatics. Am J Heal Syst Pharm. 2014;71(3):247-50.

3. Desselle SP, Holmes ER. Results of the 2015 national certified pharmacy technician workforce survey. Am J Heal Pharm. 2017;74(13):981-91.

4. Shane R. Advancing technician roles: An essential step in pharmacy practice model reform. Am J Heal Pharm. 2011;68(19):1834-5.

5. Fera $T$, Kanel KT, Bolinger ML, Fink AE, Iheasirim S. Clinical support role for a pharmacy technician within a primary care resource center. Am J Heal Pharm. 2018;75(3):139-44.

6. Porkelsson J. The Impact of Communication Factors on Job Satisfaction Among Icelandic Employees in the Public Sector. Reykjavík University. 2018.

7. Coburn MJ, Gagnon JP, Eckel FM. Job satisfaction of hospital pharmacy technicians in North Carolina. Am J Heal Pharm. 1980;37(3):359-64.

8. Sanford ME, Facchinetti NJ, Broadhead RS. Observational study of job satisfaction in hospital pharmacy technicians. Am J Heal Pharm. 1984;41(12):2599-606.

9. Cortese LM, Greenberger DW, Schneider PJ, Bourret JA. Job characteristics and satisfaction of pharmacy technicians. Am J Heal Pharm. 1987;44(11):2514-8.

10. Mahoney CD, Gallina JN, Jeffrey LP. A comprehensive program to increase job satisfaction among pharmacy technicians. Hosp Pharm. 1982;17(10):547-50. 